\title{
Induced phagotrophy in the photosynthetic dinoflagellate Heterocapsa triquetra
}

\author{
Catherine Legrand*, Edna Granéli, Per Carlsson
}

Department of Natural Sciences, University of Kalmar, Box 905, S-39129 Kalmar, Sweden

\begin{abstract}
Mixotrophy by the photosynthetic dinoflagellate Heterocapsa triquetra was investigated using fluorescently labelled algae (FLA) (size 1, 3,6 $\mu \mathrm{m}$ ). Experiments were conducted in nitrogen-and phosphorus-replete/depleted medium under light and dark conditions. Incubations ranged from several hours to several days. The dinoflagellate was capable of phagotrophy when exposed to light and dark periods in nutrient-depleted medium. H. triquetra showed similar ingestion rates in the light (range: 0.1 to 0.4 FLA dino $0^{-1} \mathrm{~d}^{-1}$ ) and in the dark (range: 0.06 to $0.4 \mathrm{FLA} \mathrm{dino}^{-1} \mathrm{~d}^{-1}$ ). The dinoflagellate was able to selectively ingest the different FlA. The cyanobacterium Synechococcus sp. was not ingested whereas a small round flagellate and the diatom Thalassiosira pseudonana were observed inside the cells. The flagellate was ingested at higher rates than the diatom in both the light and the dark. About $40 \%$ of the labelled flagellate was removed from the suspension by $H$. triquetra in the light and $22 \%$ in the dark. The diatom was removed from the suspension at the same rate (27 to $30 \%)$ in both light and dark treatments. After $5 \mathrm{~d}$ incubation in nutrient-depleted medium and no addition of FLA, the proportion of small $H$. triquetra cells $\left(<1000 \mu \mathrm{m}^{3}\right)$ increased from 50 to over $75 \%$. In the presence of FLA, the distribution of $H$. triquetra cell volumes showed that the proportion of larger cells $\left(>2000 \mu \mathrm{m}^{3}\right)$ increased from 6 to $>20 \%$ during long incubations in the light and the dark. Since the frequency of observed cells with ingested FLA varied from 3 to $20 \%$ for the same period, the proportion of larger cells may be the phagotrophic proportion of the population. However, only 8 (dark) to $12 \%$ (light) of the observed $\mathrm{H}$. triquetra cell volume increase can be explained in terms of carbon from the ingestion of fluorescently labelled phytoplankton. We conclude that phagotrophy in $H$. triquetra may be important in maintaining the population in environments of low nutrient concentration and low light intensity.
\end{abstract}

KEY WORDS: Phagotrophy - Mixotrophy · FLA - Nutrient limitation - Light limitation - Peridiniales Heterocapsa triquetra

\section{INTRODUCTION}

The idea that algae can ingest particles as a supplementary mode of nutrition is not new. Hofeneder (1930) reported that the freshwater dinoflagellate Ceratium hirundinella engulfed algae by extruding a pseudopod which was subsequently used to bring the prey inside the cell through the ventral area. Manton \& Parke (1962) suggested that the prymnesiophyte Chrysochromulina polylepis was not a strict autotroph, due to the presence of red-brown pellets inside the cells which they believed were remains of ingested organisms.

\footnotetext{
·E-mail: catherine.legrand@ng.hik.se
}

Observations with light microscopy have been used to identify ingested organisms in mixotrophic dinoflagellates. Ingested ciliates, dinoflagellates and diatoms have been identified in Ceratium furca, Gymnodinium sanguineum, and Gyrodinium uncatenatum using the protargol technique (Bockstahler \& Coats 1993a). The development of transmission electron microscopy has also made it possible to identify bacteria and ciliate remains inside dinoflagellate cells (Jacobson \& Andersen 1994, Jacobson \& Anderson 1996). Using this technique, Jacobson \& Andersen (1994) showed the presence of food vacuoles in some photosynthetic dinoflagellates (e.g. Dinophysis). Methods developed to quantify ingestion of bacteria or algae by ciliates and heterotrophic flagellates have been employed to study phagotrophy in photosynthetic algae (i.e. Bird \& 
Kalff 1987, Tranvik et al, 1989, Sanders et al. 1990 Nygaard \& Tobiesen 1993. Keller et al. 1994, Arenovski et al. 1995, present study). Ingested CMFDAstained protists and phycoerythrin-rich flagellate material has been observed in several mixotrophic dinoflagellates using epifluorescence microscopy (Li et al. 1996, Stoecker et al. 1997).

Dense blooms of dinoflagellates have occurred regularly since 1979 in the coastal waters of western Sweden (Olsson \& Edler 1991). Maximal cell densities are often observed in subsurface nutrient-depleted waters (late summer). The species (e.g. Ceratium spp.) occurring in these blooms have their maximal growth rate in deep layers where light intensities are low (Olsson \& Graneli 1991). The ability of phytoplankton cells to develop and divide in such conditions would seem to require acquisition of additional energy and nutrients by non-photosynthetic means such as mixotrophy. Mixotrophic behaviour has been recorded among several bloom-forming dinoflagellates (Bockstahler \& Coats 1993a, Jacobson \& Anderson 1996, Li et al. 1996. Stoecker et al. 1997) and feeding may be an important aspect of the ecology of these species.

There may be different advantages of mixotrophy in different algal taxa, depending on nutrient requirements. In nutrient-limited waters, the importance of phagotrophy as phosphorus or nitrogen source for some mixotrophic species has been shown. By feeding radioactively labelled bacteria to photosynthetic dinoflagellates (e.g. Alexandrium tamarense), Nygaard \& Tobiesen (1993) showed that up to $100 \%$ of the phosphorus requirements of dinoflagellates could be supplied by phagotrophy. In $\mathrm{N}$-limited surface waters of Chesapeake Bay, USA, the dinoflagellate Gymnodinium sanguineum could potentially meet $15 \%$ of its nitrogen requirement through the ingestion of small ciliates (Bockstahler \& Coats 1993b). In contrast, phagotrophy in the dinoflagellate Fragilidium subglobosum occurs in nutrient-replete B-medium and is not related to nutrient limitation (Skovgaard 1996). Bacterivory in the non-dinoflagellate Dinobryon cylindricum (chrysophyte) provides a source of organic growth factors (i.e. vitamins) and/or mineral nutrients when dissolved forms are depleted (Caron et al. 1993).

Under low light conditions, the advantage of mixotrophy is considered to be due to the additional carbon source to balance low photosynthesis (Bird \& Kalff 1987). Mixotrophy by photosynthetic algae may not provide them with all the necessary elements to grow (Sanders \& Porter 1988) but it may be enough to keep them alive under adverse light conditions

The aims of the present study were to investigate the potential for phagotrophy in the photosynthetic dinoflagellate Heterocapsa triquetra when growing under favourable and adverse nutrient and light conditions (nitrogen and phosphorus sufficiency/deficiency and light/darkness). Phagotrophy and particle size selection by the dinoflagellate were quantified using different sizes of fluorescently labelled algae (FLA).

\section{MATERIALS AND METHODS}

Phytoplankton cultures. The photosynthetic dinoflagellate species Heterocapsa triquetra (LAC25SK91) was isolated from the Skagerrak (Sweden). Batch cultures were grown in $\mathrm{f} / 2$ and $\mathrm{f} / 4$ medium (Guillard \& Ryther 1962) at a temperature of $16^{\circ} \mathrm{C}$, salinity of $26 \%$ and with a level of photosynthetically active radiation (PAR) of $100 \mu \mathrm{mol} \mathrm{m} \mathrm{m}^{-2} \mathrm{~s}^{-1}$ under a $16 / 8 \mathrm{~h} \mathrm{light/dark}$ cycle. The algae used as FLA were a small unidentified autotrophic flagellate (LAC11JA88, $3 \mu \mathrm{m}$ ), the cyanobacterium Synechococcus (LAC10SK86, $1 \mu \mathrm{m}$ ) and the diatom Thalassiosira pseudonana (LAC23SK86, $6 \mu \mathrm{m}$ ). Cultures used in this study were obtained from the Lund Algal Collection (LAC) (Dept of Marine Ecology, Lund, Sweden).

FLA preparation. We followed the procedure of Rublee \& Gallegos (1989) adapted from the method of Sherr et al. (1987) for preparing fluorescing bacteria. However, to ensure a low phosphorus concentration in the seawater, no phosphate buffer was used to dilute FLA just before its addition to the Heterocapsa triquetra culture. The algae used as FLA (flagellates, cyanobacteria, diatoms) were stained with 5-(4,6-dichlorotriazin-2-yl) aminofluorescein (DTAF). Ingested cells were enumerated and identified by size differences using epifluorescence microscopy.

Experimental designs. (1) Phagotrophy of Heterocapsa triquetra under nutrient-replete versus nutrientdepleted conditions (Expt A): To test phagotrophy by $H$. triquetra under nutrient sufficiency, cells were harvested during exponential growth in $f / 2$ medium. To obtain nutrient-depleted conditions, batch cultures which were grown in $\mathrm{f} / 4$ medium were diluted with filtered (GF/F) sea water (salinity $=26 \%, \mathrm{NO}_{3}=$ $0.08 \mu \mathrm{M}$ and $\mathrm{PO}_{4}=0.01 \mu \mathrm{M}$ ) in late exponential phase, 3 times in succession (every second day) Cultures were diluted each time by a factor of $5(200 \mathrm{ml}$ of the culture was poured into $800 \mathrm{ml}$ filtered seawater). This dilution process was to ensure that nutrient concentrations would be low.

A mixture of fluorescently labelled flagellates and cyanobacteria $(10 \mathrm{ml})$ was added to $1 \mathrm{l}$ of nutrientreplete/depleted dinoflagellate culture $\left(5 \times 10^{3}\right.$ cells $\mathrm{ml}^{-1}$ ) and mixed by gentle shaking. The initial abundance of each FLA species was $6 \times 10^{3}$ cells $\mathrm{ml}^{-1}$. Aliquots from these mixtures (dinoflagellates + FLA) were incubated in $60 \mathrm{ml}$ tissue culture flasks (4 replicates) in the light $\left(100 \mu \mathrm{mol} \mathrm{m} \mathrm{m}^{-2} \mathrm{~s}^{-1}\right)$ and the dark. 
Uptake of FLA by Heterocapsa triquetra was monitored over time for $48 \mathrm{~h}$. Samples were removed immediately (time zero) and at selected intervals $(0,0.5,1,2$, $3,6,12,24,48 \mathrm{~h}$ ) and were fixed with Lugol's solution and formalin ( $2 \%$ final concentration).

(2) Particle size selection by Heterocapsa triquetra in nutrient deplete medium (Expt B): Three different sizes of FLA (cyanobacteria, flagellates, diatoms) were used in these experiments. $H$. triquetra cells were maintained in nutrient-depleted conditions as described for Expt A. After the addition of the FLA mixture (cyanobacteria + flagellates + diatoms) $(10 \mathrm{ml})$ to the 1 l culture of $H$. triquetra (initial abundance: $3 \times$ $10^{3}$ cells $\mathrm{ml}^{-1}$ ), 20 aliquots were incubated in $60 \mathrm{ml}$ tissue culture flasks. Two parallel sets of treatments were run, one in the dark and one in the light. The relative density of each FLA species was $3 \times 10^{3}$ cells $\mathrm{ml}^{-1}$ (diatom), $6 \times 10^{3}$ cells $\mathrm{ml}^{-1}$ (cyanobacteria), and $6 \times 10^{3}$ cells $\mathrm{ml}^{-1}$ (flagellate). The flasks were gently shaken twice a day to allow the resuspension of FLA in the medium. Cultures were monitored for $5 \mathrm{~d}$, with 4 replicates sampled at each time $(0,6,24,48,111 \mathrm{~h})$ for FLA and $H$. triquetra enumeration. $H$. triquetra cell volumes were measured at 0,24, 48 and $111 \mathrm{~h}$. Control flasks contained $H$. triquetra and no FLA. Volumes and numbers of $H$. triquetra cells were quantified from these flasks initially and at $111 \mathrm{~h}$. Dimensions of at least 50 cells were measured for calculations of cell volumes. Stereometric formulae in Edler (1979) were followed and cell carbon was then calculated using a conversion factor of $0.13 \mathrm{pg} \mathrm{C} \mu \mathrm{m}^{-3}$ for the dinoflagellate (Smetacek 1975) and $0.11 \mathrm{pg} \mathrm{C} \mathrm{mm}^{-3}$ for the FLA (Strathmann 1967).

(3) Effect of bacterial/chemical decomposition on FLA (Expt C): This was studied in the absence of Heterocapsa triquetra cells. $500 \mathrm{ml}$ of $H$. triquetra culture was filtered on a $3 \mu \mathrm{m}$ polycarbonate membrane. After the addition of FLA mixture (diatoms, flagellates and cyanobacteria) to the filtrate, 2 sets of 3 replicates were incubated in $60 \mathrm{ml}$ tissue culture flasks in the dark and the light. FLA species densities were counted initially and at $111 \mathrm{~h}$.

Analytical methods. (1) Cell counts: Cell abundance of Heterocapsa triquetra was determined on samples fixed using Lugol's solution using a particle counter with a $400 \mu \mathrm{m}$ aperture (HIAC/ROYCO 9064). Samples for counting FLA were fixed with Lugol's and formalin ( $2 \%$ final concentration). The brown colour of Lugol's solution was bleached by adding 1 or 2 drops of sodium thiosulfate $(3 \%)$. FLA were counted after filtration of 4 to $5 \mathrm{ml}$ subsample on $0.2 \mu \mathrm{m}$ black Nuclepore filters. The mounted samples were kept frozen until microscopic observation. At least 80 to 100 cells of $H$. triquetra were counted for each replicate in the uptake experiments. The number of FLA counted was at least 300 for each replicate in the disappearance experiments. Observation of $H$. triquetra cells and enumeration of FLA were performed using a Leitz Dialux 20 EB epifluorescence microscope equipped with a BP450-490 excitation filter, a 515 barrier filter and a 510 beam splitter.

(2) Estimation of ingestion rates of FLA by Heterocapsa triquetra: Subsamples were fixed immediately after the addition of FLA to $H$. triquetra cultures so that a time zero value of ingested FLA per dinoflagellate cell could be determined. This value was used as a blank and subtracted from the number of ingested FLA observed in each sample. During short-term incubation (Expt A), ingestion rate (FLA dino $o^{-1} \mathrm{~d}^{-1}$ ) was calculated from the slope of the number of FLA per dinoflagellate cell versus time.

During long-term incubation (Expt B), ingestion rate $\left(I_{B}\right)$ (FLA dino ${ }^{-1} \mathrm{~d}^{-1}$ ) was calculated from the disappearance of FLA in the suspension during the incubation: $I_{\mathrm{B}}=\mathrm{FLA} / t H_{\mathrm{B}}$ where FLA is the amount of FLA removed from the suspension during the interval being considered, $H_{\mathrm{B}}$ is the mean cell number of Heterocapsa triquetra (cells $\mathrm{ml}^{-1}$ ) during the incubation, and $t$ the incubation time (days).

\section{RESULTS}

\section{Ingestion of FLA under nutrient-replete versus nutrient-depleted conditions}

In nutrient-replete medium (f/4), no ingested FLA were observed inside Heterocapsa triquetra cells incubated in the light and/or the dark (Expt A), therefore no data are presented. In nutrient-deficient medium, $H$. triquetra ingested FLA cells under both light and dark conditions (Expt A; Fig. 1). FLA were detectable inside $H$. triquetra cells after $30 \mathrm{~min}$ in short-term incubations (Expt $A$; Fig. 1). The number of FLA ingested per cell was linear for the first $6 \mathrm{~h}$ of incubation in the light and the dark but decreased thereafter (Fig. 1). Ingestion rates of FLA by $H$. triquetra (calculated by linear regression over $6 \mathrm{~h}$ ) were higher in the dark $\left(0.38 \pm 0.12\right.$ FLA dino $\left.{ }^{-1} \mathrm{~d}^{-1}\right)$ than in the light $\left(0.16 \pm 0.03\right.$ FLA dino $\left.^{-1} \mathrm{~d}^{-1}\right)$ (Table 1$)$. In these shortterm incubations (Expt A), only the fluorescent flagellate was observed inside $H$. triquetra, suggesting that Synechococcus cells were not ingested by the dinoflagellate.

\section{Particle size selection under nutrient-depleted conditions}

In Expt B, the ratio between the 3 FLA types did not vary significantly during the long-term incubation 


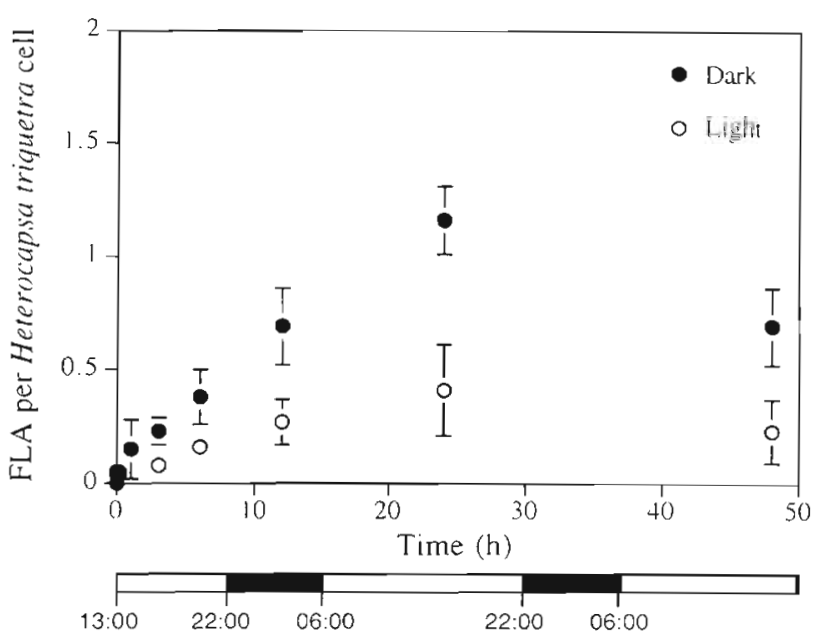

Fig. 1. Number of fluorescently labelled algae (FLA) ingested per Heterocapsa triquetra cell in nutrient-depleted cultures in the light at an intensity of $100 \mu \mathrm{mol} \mathrm{m} \mathrm{m}^{-2} \mathrm{~s}^{-1}$ on a $16 / 8 \mathrm{~h}$ light/dark cycle (Light) and in continuous darkness (Dark) (Expt A). Black and white bars indicate dark and light periods. Errors are \pm standard deviation based on replicate cultures $(n=4)$ for each treatment

(Table 2), indicating no quantitative or qualitative change in prey availibility. In samples taken after $6 \mathrm{~h}$ of incubation in the dark and/or the light, only the fluorescent flagellate was observed inside Heterocapsa triquetra, consistent with Expt A. Mean ingestion rates of the fluorescent flagellate were thus calculated assuming that the uptake of FLA was linear over $6 \mathrm{~h}$ (as in Expt A; Fig. 1). Ingestion rates were found to be lower in the light $\left(0.10 \pm 0.04 \mathrm{FLA} \mathrm{dino}^{-1} \mathrm{~d}^{-1}\right)$ than in the dark $\left(0.28 \pm 0.12\right.$ FLA dino $\left.o^{-1} \mathrm{~d}^{-1}\right)$ but comparable to those previously calculated in Expt A (Table 1). Fluorescent diatoms were observed inside $H$. triquetra cells in samples taken after 24,48 and 111 h dark incubation. For the first $24 \mathrm{~h}, H$. triquetra ingested only the flagellate but thereafter consumed both $T$. pseudonana and small flagellates (Fig. 2). After $24 \mathrm{~h}$, the percentage of ingested $T$. pseudonana increased from 0 to $44 \%$ of the total number of ingested FLA in the dark (Fig. 2). Some cells of $H$. triquetra contained a larger, yellowish dinoflagellate-like structure after $111 \mathrm{~h}$ of dark exposure. This particle structure was not recognizable as the fluorescent diatom.

\section{Phagotrophy in the light versus the dark}

Mean ingestion rates of each FLA were calculated by the disappearance of FLA (Table 2) from the suspension medium over the $111 \mathrm{~h}$ incubation period. Disappearance rates of the flagellate and the diatom by Heterocapsa triquetra cells maintained in the dark were lower compared to cells incubated in the light (Table 1). In dark incubations, fluorescent flagellates disappeared more rapidly $(0.15 \pm$ 0.04 FLA dino $\left.^{-1} \mathrm{~d}^{-1}\right)$ compared to fluorescent diatoms $\left(0.07 \pm 0.02 \mathrm{FLA} \mathrm{dino}^{-1}\right.$ $\mathrm{d}^{-1}$ ) (Table 1). In light incubations, disappearance rates were comparable to dark values for the fluorescent diatom $\left(0.09 \pm 0.02\right.$ FLA dino $\left.^{-1} \mathrm{~d}^{-1}\right)$ but significantly higher for the fluorescent flagellate $\left(0.31 \pm 0.07\right.$ FLA dino $\left.{ }^{-1} \mathrm{~d}^{-1}\right)$ (Table 1). This contradicts previously calculated figures of (1) the ingestion rates calculated over the first $6 \mathrm{~h}$ incu-

Table 2. Ingestion rates of Ieterocapsa triquetra determined in nutrient-depleted cultures in the light (L) at an intensity of $100 \mu \mathrm{mol} \mathrm{m} \mathrm{m}^{-2} \mathrm{~s}^{-1}$ and in the dark (D). Ingestion rates were calculated (A) by linear regression of the number of ingested FLA (flagellate only) over $6 \mathrm{~h}$ incubation (Expts $\mathrm{A}$ and $\mathrm{B}$ ), and (B) by the disappearance of FLA (flagellate + diatom) from suspension over $111 \mathrm{~h}$ incubation (Expt B). Errors are \pm 1 standard deviation based on replicate cultures $(n=4)$ in each treatment.

\begin{tabular}{|c|c|c|c|c|c|c|}
\hline & \multicolumn{4}{|c|}{$\begin{array}{l}\text { (A) Measured by FLA uptake } \\
\left.\text { (FLA dino } 0^{-1} \mathrm{~d}^{-1}\right\}\end{array}$} & \multirow{2}{*}{\multicolumn{2}{|c|}{$\begin{array}{c}\text { (B) Measured by FLA disappearance } \\
\left(\text { FLA dino }{ }^{-1} \mathrm{~d}^{-1} \text { ) }\right. \\
\text { Expt B }\end{array}$}} \\
\hline & \multicolumn{2}{|c|}{ Expt $A$} & \multicolumn{2}{|c|}{ Expt B } & & \\
\hline & L & $\mathrm{D}$ & $L$ & $D$ & $\mathrm{~L}$ & $\mathrm{D}$ \\
\hline FLA & $0.16 \pm 0.03$ & $0.38 \pm 0.12$ & $0.10 \pm 0.04$ & $0.28 \pm 0.12$ & $0.39 \pm 0.04$ & $0.21 \pm 0.05$ \\
\hline Flagellate & $0.16 \pm 0.03$ & $0.38 \pm 0.12$ & $0.10 \pm 0.04$ & $0.28 \pm 0.12$ & $0.31 \pm 0.07$ & $0.15 \pm 0.04$ \\
\hline T. pseudonana & $-{ }^{\circ}$ & $-{ }^{3}$ & $-{ }^{\mathrm{b}}$ & $-b$ & $0.09 \pm 0.02$ & $0.07 \pm 0.02$ \\
\hline
\end{tabular}




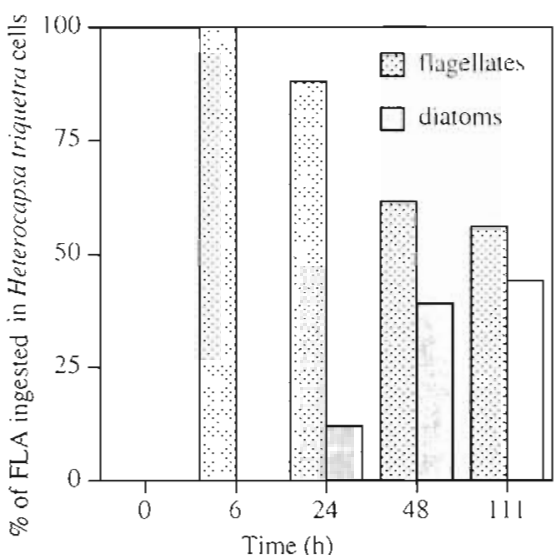

Fig. 2. Relative proportion of fluorescently labelled flagellates and diatoms ingested per Heterocapsa triquetra in nutrientdepleted cultures and in continuous darkness (Expt B). Percentage of ingested FLA was calculated as the number of flagellates and diatoms observed inside $H$. triquetra cells divided by the total number of FLA ingested

bation (Expt $A$ and $B_{i}$ Table 2) which showed a lower uptake of fluorescent flagellates in the light, and (2) the microscopical observations where fewer fluorescent diatoms were observed inside $H$. triquetra cells maintained in the light (Fig. 2).

The amount of FLA (\% of total FLA number) removed from the Heterocapsa triquetra suspension was $11 \%$ (dark) and $20 \%$ (light) for the flagellate and $27 \%$ (dark) and $30 \%$ (light) for the diatom (calculated from Table 1). Densities of each FLA type did not vary significantly during the $111 \mathrm{~h}$ dark incubation in the filtrates of $H$. triquetra (Expt C). A slight decrease $(8 \%$ of the total cells) in Thalassiosira pseudonana number was observed in light treatments (Expt $C_{\text {; }}$ Table 3 ).

\section{Effect of phagotrophy on Heterocapsa triquetra cell numbers and volumes}

The abundance of Heterocapsa triquetra cells (with addition of FLA) decreased during the incubation in both dark and light bottles (Fig. 3A). Conversely, the

Table 3. Changes in the density of FLA (cells $\mathrm{ml}^{-1}$ ) in culture filtrates of Heterocapsa triquetra incubated in the light (L) at an intensity of $100 \mu \mathrm{mol} \mathrm{m} \mathrm{m}^{-2} \mathrm{~s}^{-1}$ and in the dark (D) (Expt C). Errors are \pm 1 standard deviation based on replicate cultures $(n=3)$ in each treatment

\begin{tabular}{|cccccc|}
\hline & \multicolumn{2}{c}{ T.pseudonana } & \multicolumn{3}{c|}{ Other FLA } \\
& L & D & L & D \\
\hline Initial & $2725 \pm 219$ & $2632 \pm 213$ & $12756 \pm 665$ & $11655 \pm 801$ \\
111 h & $2507 \pm 222$ & $2709 \pm 240$ & $13134 \pm 945$ & $12203 \pm 1022$ \\
\hline
\end{tabular}
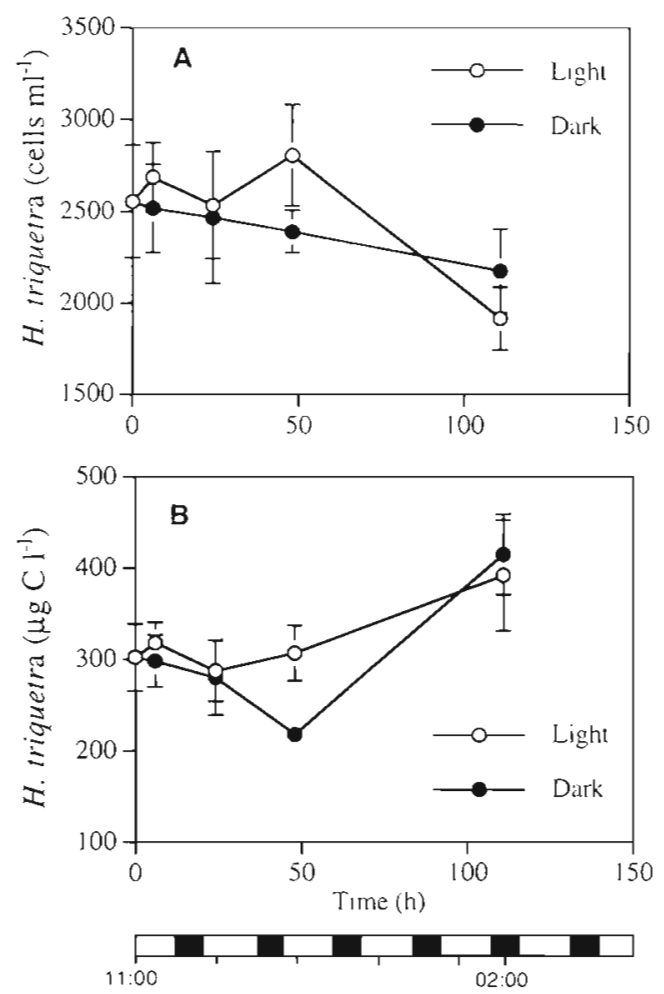

Fig. 3. (A) Growth of Heterocapsa triquetra and (B) biomass concentration in nutrient-depleted cultures in the presence of FLA in the light at an intensity of $100 \mu \mathrm{mol} \mathrm{m} \mathrm{m}^{-2} \mathrm{~s}^{-1}$ on a $16 / 8 \mathrm{~h}$ light/dark cycle (Light) and in continuous darkness (Dark) (Expt B). Black and white bars indicate dark and light periods. Carbon biomass was calculated as (cell volumes $\times 0.11 \times$ cell number). Errors are \pm standard deviation based on replicate cultures $(n=4)$ for each treatment

mean carbon biomass values of $H$. triquetra increased from 300 to $450 \mu \mathrm{g} \mathrm{Cl}^{-1}$ during the experiments in dark and light treatments (Fig. 3B). In treatments with added FLA, the average cell volume increased from $1076 \pm 664 \mu \mathrm{m}^{3}$ (initially) to $1769 \pm 768 \mu^{3}$ in the light and $1735 \pm 1297 \mu^{3}$ in the dark treatments. In the same conditions but with no FLA added, the average cell volume of $H$. triquetra decreased over the $111 \mathrm{~h}$ incubation from $1234 \pm 441 \mu^{3}$ (initially) to $784 \pm$ $272 \mu^{3}$ in the light and $526 \pm 285 \mu^{3}$ in the dark. However, these average values did not reflect the morphological changes of $H$. triquetra cells that had ingested FLA. Cells with the ingested Thalassiosira pseudonana increased up to 2 times in length in relation to a normal photosynthetic cell (an increase in cell volume between 2 and 5 times). Initially, about $90 \%$ of the cells had an average cell volume lower than $1300 \mu^{3}$ in all treatments (Fig, 4). After $111 \mathrm{~h}$ incubation in the light/dark and with addition of FLA in the cultures, the frequency of smaller cells $\left(<1000 \mu^{3}\right)$ decreased considerably from 60 to $10-20 \%$ (Fig. 4A). Concurrently, the frequency of larger cells increased 
A

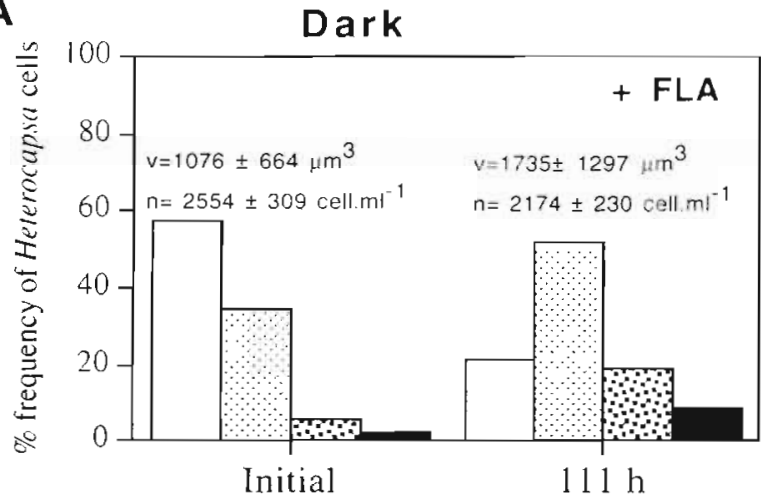

B

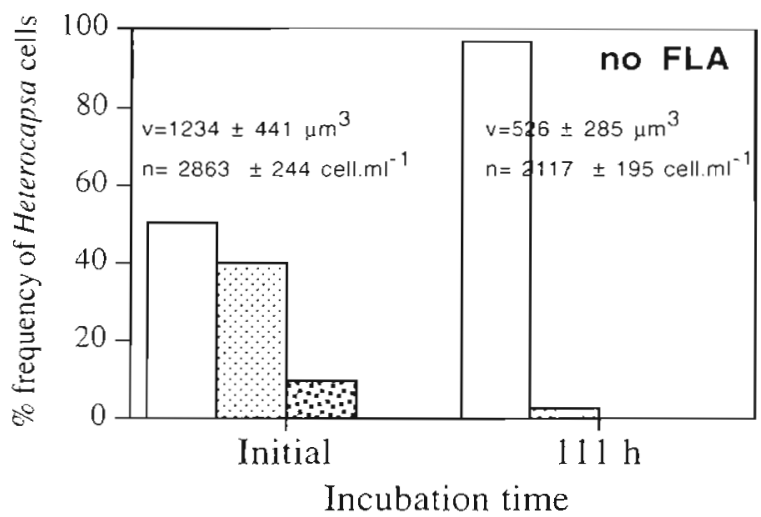

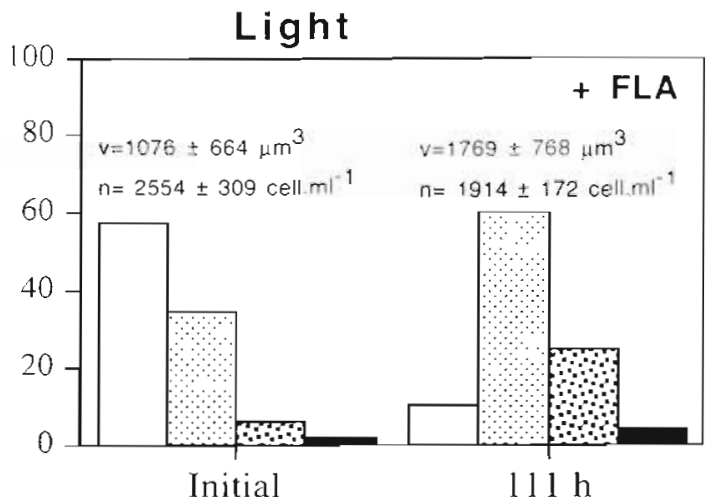

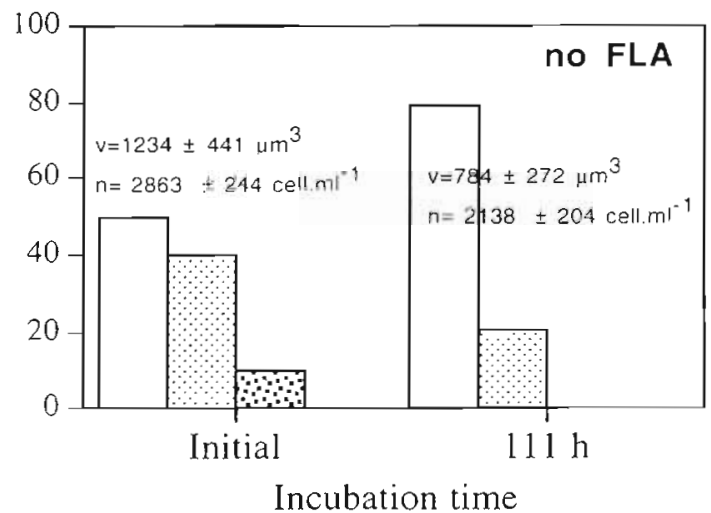

Incubation time
Cell volume $\left(\mu \mathrm{m}^{3}\right)$
$<1000$
$1000-2000$
A] 2000-3000
$>3000$

Fig. 4. Changes in cell volume (v) distribution of Heterocapsa triquetra cultured in nutrient-depleted and in light/dark conditions (A) with addition of FLA and (B) without FLA. Dimensions of at least 50 cells were measured for calculation of cell volume following stereometric formulae in Edler (1979). Errors are \pm standard deviation for H. triquetra cell volume ( $\mathrm{v}$ ) and number (n)

in the light and the dark, with increases mostly in the volume classes 1000 to 2000 and 2000 to $3000 \mu^{3}$. The frequency of the largest cells (>3000 up to $5000 \mu^{3}$ ) increased from 2 to $8 \%$ in the dark and $4 \%$ in the light (Fig. 4A). In the treatments with no addition of FLA, 80 to $96 \%$ of the cells had a volume $<1000 \mu^{3}$ and none were greater than $2000 \mu^{3}$ (Fig. 4B).

\section{Importance of phagotrophy for Heterocapsa triquetra population}

During the incubation in nutrient-depleted medium (Expt B) the number of dinoflagellate cells containing FLA cells varied between 2 and $30 \%$ of the total number of Heterocapsa triquetra cells in both the light and the dark (Fig. 5). A maximal value $(30 \pm 4 \%)$ was observed after $6 \mathrm{~h}$ of incubation in darkness, due to the ingestion of small flagellate cells. For $H$. triquetra maintained in the light, the percentage of $H$. triquetra cells observed with ingested FLA was between 3 and $12 \%$ of the total population (Fig. 5).

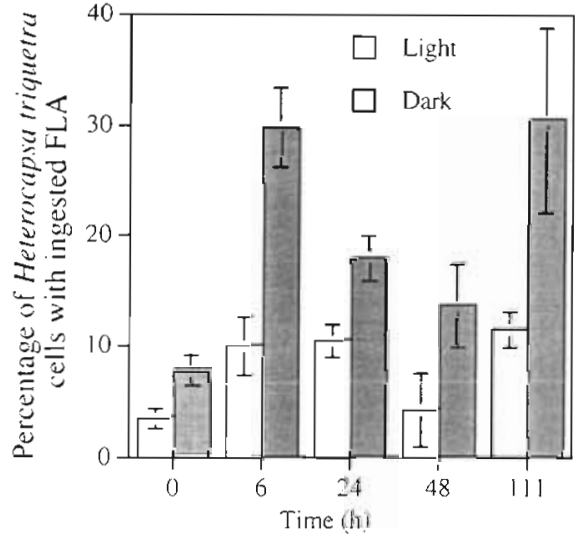

Fig. 5. Percentage of Heterocapsa triquetra cells observed with ingested FLA in nutrient-depleted cultures in the light

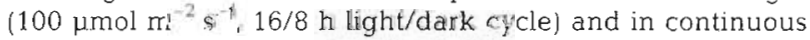
darkness (Expt B). Dinoflagellate cells were observed using epifluorescence mircoscopy. Values at $0 \mathrm{~h}$ were obtained after fixation of $H$. triquetra cell samples at time $=0$. Percentages were calculated as the total number of ingested FLA divided by the total number of $H$. triquetra cells in the cultures. Errors bars represent the standard deviation based on 4 replicates for each treatment. 


\section{DISCUSSION}

This study showed that in nutrient-depleted medium only, the thecate dinoflagellate Heterocapsa triquetra was able to ingest fluorescently labelled algae (FLA) in the light and in the dark. There was also evidence of prey size selectivity, since the dinoflagellate ingested fluorescent flagellates $(3 \mu \mathrm{m})$ and diatoms $(6 \mu \mathrm{m})$ but not cyanobacteria $(1 \mu \mathrm{m})$.

\section{Nutrient conditions}

Ingestion of FLA by Heterocapsa triquetra only occurred in nutrient-depleted medium. No ingested FLA were observed when the dinoflagellate was cultured under high nutrient conditions. These findings confirm the idea that mixotrophy may be stimulated for some mixotrophic species under limiting nitrogen and phosphorus conditions. However, there are contrasting results for different phytoplankton species. Some studies have shown that prey ingestion increased when nutrients were reduced (Nygaard \& Tobiesen 1993, Keller et al. 1994, Legrand et al. 1996) and there are others that state that mixotrophy could be particularly advantageous in nutrient-limited environments (Estep et al. 1986, Sanders 1991, Arenovski et al. 1995). However, nutrient concentration had no effect on phagotrophy for the freshwater chrysophyte Poterioochromonas malhamensis (Caron et al. 1990). Although observations of some natural plankton communities suggest that the proportion of mixotrophs is highest in nutrientlimited marine and freshwater environments (Riemann \& Christoffersen 1993, Jones 1994), high rates of ingestion by mixotrophs have been reported in a eutrophic lake (Sanders et al. 1989) and a eutrophic estuary (Chesapeake Bay) (Bockstahler \& Coats 1993a, b, Li et al. 1996, Stoecker et al. 1997). The relationship between trophic status and the number of mixotrophs or their rates of phagotrophy appears to be related to a large diversity among mixotrophic species, i.e. different species of mixotrophs ingest particles for different elements such as carbon, major nutrients, or micronutrients. In some species (e.g. Dinobryon cylindricum), the ingestion of bacteria can constitute up to $45-100 \%$ of the cellular nitrogen and phosphorus of the alga (Caron et al. 1993). Mixotrophy in $H$. triquetra could be a successful strategy for phagotrophic uptake of nitrogen and phosphorus when these elements are limiting.

\section{Light conditions}

Light levels during the incubation period also influenced FLA uptake by Heterocapsa triquetra. During short-term incubations $(<24 \mathrm{~h})$, FLA ingestion rates were higher in the dark $\left(0.28\right.$ to 0.38 FLA dino $\left.^{-1} \mathrm{~d}^{-1}\right)$ than in the light $\left(0.1\right.$ to 0.16 FLA dino $\left.o^{-1} \mathrm{~d}^{-1}\right)$. However, during the long-term incubation period (111 h), when ingestion rates were calculated by the disappearance of FLA from suspension, $H$. triquetra showed lower ingestion rates of FLA in the dark $\left(0.21 \mathrm{FLA} \mathrm{dino}^{-1} \mathrm{~d}^{-1}\right)$ compared to the light (0.39 FLA dino-1 $\left.\mathrm{d}^{-1}\right)$. As with dissolved nutrients, the effects of light on phagotrophy are not consistent between species. Earlier investigations showed that ingestion of particles by the photosynthetic flagellate Poterioochromonas malhamensis was induced at low light intensity when grazing was measured after the transfer of the cells from continuous darkness to relatively bright light (Porter 1988). In similar experiments, Sanders et al. (1990) allowed the same strain of $P$. malhamensis to adapt to various light intensities before grazing measurements and found little or no effect of light on the ingestion or growth rates of $P$. malhamensis. Aaronson (1974) suggested that light was not an important regulator of feeding for Ochromonas danica because the percentage of $O$. danica containing ingested cells remained constant during light and dark conditions. Andersson et al. (1989) reported no effect of light on the growth of a mixotrophic Ochromonas sp. isolated from the Baltic Sea except when it was maintained in axenic conditions in an organic-free medium. However, the phagotrophic uptake of bacteria by a marine Ochromonas sp., isolated from the Sargasso Sea, was lower under lightlimiting conditions (Keller et al. 1994) and growth rates of a freshwater Ochromonas sp. were greater in the light compared to the dark (Rothhaupt 1996). In the present study, the discrepancy between ingestion rates of FLA calculated from the short- (i.e. ingestion rate) and long-term (i.e. disappearance rate) incubations indicates that FLA uptake by $H$. triquetra decreased over time in the dark, provided that the disappearance of FLA was not due to significant bacterial/chemical deterioration during the incubation. Similarly, the ingestion of bacteria by Dinobryon cylindricum occurred in the dark but the cells rapidly ceased ingesting bacteria after $5 \mathrm{~d}$ (Caron et al. 1993). The potential phagotrophy of $H$. triquetra in the dark may be important in environments where light cannot support photosynthesis for short periods.

Diel cycle and circadian rhythms are important aspects in the physiology of dinoflagellates (Roenneberg 1996). Feeding by the mixotrophic dinoflagellate Prorocentrum minimum is initiated during the second half of the light period and may continue until nutrient quotas for cell division are met (Stoecker et al. 1997). One possible explanation for the discrepancy between lower uptake and higher disappearance rates of FLA in Heterocapsa triquetra cultures incubated in the light may be 
that feeding rate was regulated by nutrient quotas for photosynthesis. Ingestion rates in $H$. triquetra may have increased during the incubation when the nutrient demand created by photosynthesis was enhanced.

However, it remains unclear why the number of Heterocapsa triquetra cells observed which had ingested FLA during the long-term incubation in the light was so low ( 3 to $12 \%$ of the total cell number) and contradicted the ingestion rates calculated from the disappearance of FLA from suspension during the same period. Prey digestion is assumed to be a rapid process ( $<1 \mathrm{~h}$ ) in heterotrophic nutrition (Jones et al. 1993). In the present study, the number of FLA per cell versus time showed approximately a linear increase over $24 \mathrm{~h}$, suggesting a longer digestion process than previously reported for other mixotrophic species (Jones et al. 1993). After the initial $24 \mathrm{~h}$, microscopic observations of $H$. triquetra cells had low temporal resolution which may not be appropriate to assess the real percentage of phagotrophic cells.

\section{Prey discrimination}

Flagellates are able to differentiate particles according to their size (Bird \& Kalff 1987, Sanders \& Porter 1988), motility (Kawachi et al. 1991) or attraction as food source (Jones et al. 1993). Heterocapsa triquetra ingested heat-killed fluorescent flagellates and diatoms despite their potential low nutritional value, but ingestion rates were low. Discrimination on living versus heat-killed prey has been demonstrated for ciliates (Putt 1991), marine heterotrophic flagellates (Landry et al. 1991), and mixotrophic algal species (Jones et al. 1993). Ingestion rates in those studies were 2 to 20 times higher when grazers were feeding on living prey. Sherr et al. (1989) did not find this kind of selectivity for heterotrophic flagellates, nor did Nygaard \& Hessen (1990) for the mixotrophic flagellate Ochromonas minima.

Heterocapsa triquetra did not ingest fluorescent cyanobacteria cells but fluorescent flagellates and diatoms were observed inside the dinoflagellate. This discrimination between the cyanobacteria and the flagellate or the diatom may be related to the size of the prey. Dinoflagellates often ingest cells their own size (Hansen et al. 1994) or even larger (Skovgaard 1996, Hansen \& Nielsen 1997). These authors observed the ingestion of Ceratium spp. by a smaller dinoflagellate Fragilidium subglobosum. Their work suggests that bacteria-size prey (e.g. cyanobacteria) are too small to be ingested by dinoflagellates. Although the presence of bacteria in dinoflagellate food vacuoles has not been observed, the ingestion of radioactively prelabelled bacteria $(<1 \mu \mathrm{m})$ with ${ }^{3} \mathrm{H}$-thymidine and ${ }^{14} \mathrm{C}$-protein by various dinoflagellates has been demonstrated (Lessard \& Swift 1985, Nygaard \& Hessen 1990). However, this could be a step-wise transfer of radioactivity with heterotrophic nanoflagellates ingesting labelled bacteria and dinoflagellates ingesting the nanoflagellates. The possibility that labelled bacteria could be attached to the theca of dinoflagellates, i.e. not ingested, cannot be discarded. Several dinoflagellates were reported to ingest living 5-chloromethyl fluorescein diacetate (CMFDA)-labelled nanoflagellates (4 to $6 \mu \mathrm{m}$ ) but showed no evidence for ingestion of a CMFDA-labelled diatom during short-term incubations (4 h) (Li et al. 1996). In the present study, the FLA ingested were composed exclusively of the small flagellate during short-term incubations $(<24 \mathrm{~h})$, whereas during longterm incubations $H$. triquetra was found to also ingest the diatom Thalassiosira pseudonana. The percentage of ingested diatoms observed in $H$. triquetra cells increased from 0 to $44 \%$ (of total FLA ingested) during the $111 \mathrm{~h}$ dark incubation. This switch in food preference suggests a change in prey availability, which also has a major influence on ingestion rates (Porter 1988, Jones et al. 1993). However, the ratios between fluorescently labelled diatoms and flagellates remained constant in the suspension during the long-term incubations. $H$. triquetra ingested more flagellates $[0.1$ to $\left.0.38 \mathrm{FLA} \mathrm{dino}^{-1} \mathrm{~d}^{-1}\right)$ than diatoms (0.07 to 0.09 FLA dino $^{-1} \mathrm{~d}^{-1}$ ) in terms of FLA abundance in all treatments. However, the contribution of the diatoms to the dinoflagellate $\mathrm{C}$ requirements would be greater, assuming higher cellular carbon content in diatoms (22 pg C cell ${ }^{-1}$ ) than in flagellates (0.9 pg C cell-1).

In several cases, dinoflagellate-like structures were observed inside some Heterocapsa triquetra cells, suggesting that $H$. triquetra might be capable of cannibalism. Possible cannibalism has been reported by Wawrik (1970) at the end of a Cryptomonas sp. bloom. Indications of cannibalism have been made in Protoperidinium spp. (Jeong \& Latz 1994) and Ochromonas sp. (Aaronson 1974). In our studies, only 4 cells from the dark treatments were observed with this peculiar inclusion which looked partially digested, so if cannibalism does occur it is very infrequent. An increasing number of marine dinoflagellates are known to have sexual life cycles and under appropriate conditions gametes are produced (Cetta \& Anderson 1990, Kita et al. 1993). Gametes are generally smaller than the vegetative cell and have been observed in dense, actively growing or old (presumably nutrient depleted) laboratory cultures (Walker \& Steidinger 1979). As pointed out by Walker (1984), gamete formation is induced by many different conditions among dinoflagellates species. We can thus not exclude the possibility that the peculiar inclusion inside $H$. triquetra, resembling a small cell, could be a gamete. 


\section{Importance of mixotrophy to Heterocapsa triquetra}

Among the mixotrophic phytoplankters, phagotrophy may be a mechanism of gaining carbon (Sanders \& Porter 1988) and true phagotrophy should induce growth of the phytoplankter. In our studies, Heterocapsa triquetra cell numbers decreased during the incubations with or without addition of FLA, and there was no evidence of cell division. As discussed above, phagotrophy in $H$. triquetra may provide major nutrient sources but the inability of the dinoflagellate to divide suggests a lack of some essential element required for cell division.

In oligotrophic environments, phytoplankton cell volumes decrease when nitrogen and phosphorus are limiting (Rhee 1978, Suttle \& Harrison 1988). The large decrease of Heterocapsa triquetra cell volumes incubated without FLA in nutrient-depleted medium followed this pattern. However, these results are potentially in conflict with the cell size increase reported for $H$. triquetra in culture after depletion of nitrogen (Latasa \& Berdalet 1994). In the presence of FLA, mean $H$. triquetra cell volumes increased approximately 1.6 times during the course of the experiments.

In our study, Heterocapsa triquetra cell volume distribution showed a substantial increase (15 to $20 \%$ ) in the frequency of cells up to 2 to 3 times larger than the initial cells. Previous studies have reported an increase of the size of phagotrophic cells such as Gymnodinium spp. (Strom 1991). Goldman \& Dennett (1990) determined that the microflagellate Paraphysomonas could increase or decrease its cell volume by a factor of 5 , depending on the size of the food source. Microscopical observations of $H$. triquetra cells incubated in the dark revealed that the volume increase was partly due to the accumulation of phagocytosed cells (mainly the diatom). Based on the ingestion rates of FLA calculated from their disappearance from the suspension, we hypothesize that the same process occurred in $H$. triquetra cultures incubated in the light although, as discussed earlier, no ingested diatoms were observed inside the dinoflagellate cells

The contribution of FLA in terms of carbon to the increase in Heterocapsa triquetra cell volume was estimated from the ingestion rates calculated from the disappearance of FLA from the suspension in Expt B (Table 1), assuming an increase in the dinoflagellate cell volume of $\left[(1735-1076) \mu^{3} \times 0.13\right]=85 \mathrm{pg} \mathrm{C}$ $\mathrm{cell}^{-1}$ in the dark and [(1769-1076) $\left.\mu \mathrm{m}^{3} \times 0.13\right]=90 \mathrm{pg}$ $\mathrm{C}$ cell ${ }^{-1}$ in the light (Fig. 4). Carbon content of the fluorescent flagellate $\left(0.9 \mathrm{pg} \mathrm{C} \mathrm{cell}^{-1}\right)$ and the fluorescent diatom (22 pg C cell ${ }^{-1}$ ) were estimated from cell volume. Ingested FLA contributed $11.5 \%$ (light) and $8 \%$ (dark) carbon of $H$. triquetra cell volume increase. Given the large variations observed in the cell volume distribution, these estimations have to be taken with caution. If the extra volume gained by the $H$. triquetra cells was mostly water, our estimations of the significance of FLA as C source would be underestimated. Similar low organic carbon acquisition through phagotrophy has also been observed in the freshwater flagellates Cryptomonas sp. (Tranvik et al. 1989) and Dinobryon cylindricum (Caron et al. 1993). The low contribution of FLA to $H$. triquetra biomass suggests that alternative carbon sources were utilized to synthesize new cell material but not new cells.

Despite low ambient $\mathrm{N}$ and $\mathrm{P}$ levels some algal cells can store sufficient intracellular nutrients for several subsequent divisions (Pollingher et al. 1988). Chlorella ellipsoida can increase in cell number 4 -fold during dim light exposure and then remains in the stationary phase despite a continual decrease in cell volume (Tamiya et al. 1953). In the absence of FLA, Heterocapsa triquetra biomass decreased dramatically and this does not support the sole utilization of intracellular storage products to sustain the dinoflagellate biomass increase with addition of FLA. The low ingestion rate of FLA by $H$. triquetra reported in this study could be explained by a reasonable supply of dissolved organic substances present in the seawater used for the experiment (Carlsson et al. 1993). H. triquetra has the ability to utilize dissolved organic carbon (Morrill \& Loeblich 1979). In addition, there was probably significant leaching of organic material from the heat-killed FLA and from the lysed $H$. triquetra cells during the incubation. This may have led to the uptake of organic substances and may explain the discrepancy between biomass increase and FLA ingestion. Poterioochromonas malhamensis particle ingestion was shown to be inhibited by increasing glucose concentrations in laboratory experiments (Porter 1988). However, Sanders et al. (1990) found no indication that high concentrations of glucose, vitamins or dissolved inorganic $\mathrm{N}$ and $\mathrm{P}$ inhibited grazing by the same strain of Poterioochromonas. Therefore it remains unclear whether the dinoflagellate $H$. triquetra was capable of osmotrophy and phagotrophy at the same time.

In conclusion, we have shown that Heterocapsa triquetra was capable of phagotrophy in nitrogen- and phosphorus-depleted medium, ingesting FLA under dark and light conditions. Phagotrophy was higher in the dark during short $(<24 \mathrm{~h})$ incubations. However, the ingestion of FLA by $H$. triquetra increased in the light over longer periods ( 4 to $5 \mathrm{~d}$ ). The dinoflagellate was observed to discriminate between different types of FLA, ingesting flagellates and diatoms but not cyanobacteria. In these studies, phagotrophy by $H$. triquetra only contributed to a low extent $(<10 \%)$ to the total carbon budget of the entire population as has been shown for other oceanic nanoflagellates (Estep et 
al. 1986). The low ingestion rates of FLA by $H$. triquetra and the absence of dividing cells observed in these studies call into question the importance of phagotrophy for the growth of this dinoflagellate. Phagotrophy in $H$. triquetra may have a potential importance in the maintenance of the population biomass in environments where light or nutrients cannot fully support photosynthesis.

Acknowledgements. The authors thank M. Denward for his helpful technical assistance, R. W. Sanders and 3 anonymous reviewers for encouraging comments on an earlier version of this paper. We are grateful to M. Doblin for editing the English. This work has been partially supported by the European Commission Marine Sciences and Technology, Mobility and Training Research Program (contract no. MAS2-CT93-5010 to C.L.) and by the Swedish Natural Sciences Research Council (contract holder E. G.)

\section{LITERATURE CITED}

Aaronson S (1974) The biology and ultrastructure of phagotrophy in Ochromonas danica (Chrysophyceae, Chrysomonadida). J Gen Microbiol 83:21-29

Andersson A, Falk S, Samuelsson G, Hagström $\AA$ (1989) Nutritional characteristics of a mixotrophic nanoflagellate, Ochromonas sp. Microb Ecol 17:251-262

Arenovski AL, Lim EL, Caron DA (1995) Mixotrophic nanoplankton in oligotrophic surface waters of the Sargasso Sea may employ phagotrophy to obtain major nutrients. J Plankton Res 17:801-820

Bird DF, Kalff J (1987) Algal phagotrophy: regulating factors and importance of photosynthesis in Dinobryon (Chrysophyceae). Limnol Oceanogr 32:277-284

Bockstahler KR, Coats DW (1993a) Spatial and temporal aspects of mixotrophy in Chesapeake Bay dinoflagellates. J Euk Microbiol 40:49-60

Bockstahler KR, Coats DW (1993b) Grazing of the mixotrophic dinoflagellate Gymnodinium sanguineum on ciliate populations of Chesapeake Bay. Mar Biol 1.16:477-487

Carlsson P, Segatto AZ, Granéli E (1993) Nitrogen bound to humic matter of terrestrial origin - a nitrogen pool for coastal phytoplankton. Mar Ecol Prog Ser 97:105-116

Caron DA, Porter KG. Sanders RW (1990) Carbon, nitrogen and phosphorus budgets for the mixotrophic phytoflagellate Poterioochromonas malhamensis (Chrysophyceae) during bacterial ingestion. Limnol Oceanogr 35:433-443

Caron DA, Sanders RW, Lim EL, Marrasé C. Amaral LA, Whitney S, Aoki RB, Porter KG (1993) Light-dependent phagotrophy in the freshwater Dinobryon cylindricum. Microb Ecol 25:93-111

Cetta CM, Anderson DM (1990) Cell cycle studies of the dinoflagellates Gonyaulax polyedra Stein and Gyrodinium uncatenum Hulburt during asexual and sexual reproduction. J Exp Mar Biol Ecol 135(1):69-84

Edler L (1979) Recommendations on methods for marine biological studies in the Baltic Sea - phytoplankton and chlorophyll. The Baltic Marine Biologists (BMB) Publ no. $5, \mathrm{p} 1-38$

Estep KW, Davis PG, Keller MD, Sieburth JM (1986) How important are oceanic algal flagellates in bacterivory? Limnol Oceanogr 31:646-650

Goldman JC, Dennett MR (1990) Dynamics of prey selection by an omnivorous flagellate. Mar Ecol Prog Ser 59:183-194

Guillard RRL, Ryther JH (1962) Studies of marine planktonic diatoms I. Cyclotella nana Hustedt and Detonula confervacea (Cleve) Gran. Can J Microbiol 8:229-239

Hansen B, Bjornsen PK, Hansen PJ (1.994) The size ratio between planktonic predators and their prey. Limnol Oceanogr 39(2):395-403

Hansen PJ, Nielsen TG (1997) Mixotrophic feeding of Fragilidium subglobosum (Dinophyceae) on three species of Ceratium: effects of prey concentration, prey species and light intensity. Mar Ecol Prog Ser 147:187-196

Hofeneder H (1930) Über die animalische Ernährung von Ceratium hirundinella O.F. Müller and über die Rolle des Kernes bei dieser Zellfunktion. Arch Protistenkde 71:1-32

Jacobson DM, Andersen RA (1994) The discovery of mixotrophy in photosynthetic species of Dinophysis (Dinophyceae): light and electron microscopical observations of food vacuoles in Dinophysis acuminata, D. norvegica and two heterotrophic dinophysoid flagellates. Phycologia 33: 97-110

Jacobson DM, Anderson DM (1996) Widespread phagocytosis of ciliates and other protists by marine mixotrophic and heterotrophic thecate dinoflagellates. J Phycol 32:279-285

Jeong HJ, Latz MI (1994) Growth and grazing rates of the heterotrophic dinoflagellates Protoperidinium spp. on red tide dinoflagellates. Mar Ecol Prog Ser 106:173-185

Jones HLJ, Leadbeater BSC, Green JC (1993) Mixotrophy in marine species of Chrysochromulina (Prymnesiophyceae): ingestion and digestion of a small green flagellate. J Mar Biol Assoc UK 73:283-296

Jones RI (1994) Mixotrophy in planktonic protists as a spectrum of nutritional strategies. Mar Microb Food Webs 8 : $87-96$

Kawachi M, Inouye I, Maeda O, Chihara M (1991) The haptonema as a food capturing device: observations in Chrysochromulina hirta (Prymnesiophyceae). Phycologia 30: $563-573$

Keller MD, Shapiro LP, Haugen EM, Cucci TL, Sherr EB, Sherr BF (1994) Phagotrophy of fluorescently labelled bacteria by an oceanic phytoplankter. Microb Ecol 28: $39-52$

Kita T, Fukuyo Y, Tokuda H, Hirano R (1993) Sexual reproduction of Alexandrium hiranoi dinophyceae. Bull Plankton Soc Jpn 39(2):79-85

Landry MR, Lehner-Foumier JM, Sundstrom. JA, Fagerness VL, Selph KE (1991) Discrimination between Iiving and heat-killed prey by a marine zooflagellate Paraphysomonas vestita Stokes. J Exp Mar Biol Ecol 146(2):139-152

Latasa M. Berdalet E (1994) Effect of nitrogen and phosphorus starvation on pigment composition of cultured Heterocapsa sp. J Plankton Res 16:83-94

Legrand C. Saemunsdottir S. Granéli E (1996) Phagotrophy in Chrysochromulina polylepis (Prymnesiophyceae): ingestion of fluorescent labelled algae (FLA) under different nutrient conditions. In: Yasumoto T, Oshima Y, Fukuyo Y (eds) Harmful and toxic algal blooms. Intergovernmental Oceanographic Commission of UNESCO, Paris, p 339-342

Lessard E, Swift E (1985) Species-specific grazing rates of heterotrophic dinoflagellates in oceanic waters measured with a dual-label radioisotope technique. Mar Biol 87: $289-296$

Li A, Stoecker DK, Coats DW, Adams EJ (1996) Ingestion of fluorescently labelled and phycoerythrin-containing prey by mixotrophic dinoflagellates. Aquat Microb Ecol 10(2): $139-147$

Manton I, Parke M (1962) Preliminary observations on scales and their mode of origin in Chrysochromulina polylepis 
sp. nov. J Mar Biol Assoc UK 42:565-578

Morrill LC, Loeblich AR III (1979) An investigation of heterotrophic and photoheterotrophic capabilities in marine pyrrhophyta. Phycologia 18:394-404

Nygaard K, Hessen DO (1990) Use of ${ }^{14} \mathrm{C}$-protein labelled bacteria for estimating rates by heterotrophic and mixotrophic flagellates. Mar Ecol Prog Ser 68:7-14

Nygaard K, Tobiesen A. (1993) Bacterivory in algae: a survival strategy during nutrient limitation. Limnol Oceanogr 38: $273-279$

Olsson P, Edler L (1991) Dinoflagellate distribution in the southeastern Kattegat during an autumn bloom. Sarsia 76: 23-28

Olsson P, Granéli E (1991) Observations on diurnal vertical migration and phased cell division for three coexisting marine dinoflagellates. J Plankton Res 13:1313-1324

Pollingher U, Berman T, Kaplan B, Scharf D (1988) Lake Kinneret phytoplankton: response to $\mathrm{N}$ and $\mathrm{P}$ enrichments in experiments and in nature. Hydrobiologia 166:65-75

Porter KG (1988) Phagotrophic phytoflagellates in microbial food webs. Hydrobiologia 159:89-97

Putt M (1991) Development and evaluation of tracer particles for use in microzooplankton herbivory studies. Mar Ecol Prog Ser 77(1):27-37

Rhee GY (1978) Effect of N:P atomic ratios and nitrate limitation on algal growth, cell composition and $\mathrm{NO}_{3}$ uptake. Limnol Oceanogr 23:10-25

Riemann B, Christoffersen K (1993) Microbial trophodynamics in freshwater. Mar Microb Food Webs 7:69-100

Roenneberg $\mathrm{T}$ (1996) The complex circadian system in Gonyaulax polyedra. Physiol Plant 96:733-737

Rothhaupt KO (1996) Utilization of substitutable carbon and phosphorus sources by the mixotrophic chrysophyte Ochromonas sp. Ecology 77(3):706-715

Rublee PA, Gallegos CL (1989) Use of fluorescently labelled algae (FLA) to estimate microzooplankton grazing. Mar Ecol Prog Ser 51:221-227

Sanders RW (1991) Mixotrophic protists in marine and freshwater ecosystems. J Protozool 38:76-81

Sanders RW, Porter KG (1988) Phagotrophic phytoflagellates. Adv Microb Ecol 10:167-192

Sanders RW, Porter KG, Bennett. SJ, DeBiase AE (1989) Seasonal patterns of bacterivory by flagellates, ciliates, rotifers, and cladocerans in a freshwater planktonic community. Limnol Oceanogr 34:673-687

Editorial responsibility: Robert Sanders,

Philadelphia, Pennsylvania, USA
Sanders RW, Porter KG, Caron DA (1990) Relationship between phototrophy and phagotrophy in the mixotrophic chrysophyte Poterioochromonas malhamensis. Microb Ecol 19:97-109

Sherr EB, Sherr BF, Fallon RD (1987) Use of monodispersed fluorescently labelled bacteria to estimate in situ protozoan bacterivory. Appl Environ Mirobiol 53:958-965

Sherr EB, Sherr BF, Pedrós-Alió C (1989) Simultaneous measurement of bacterioplankton production and protozoan bacterivory in estuarine water Mar Ecol Prog Ser 54(3) $209-219$

Skovgaard A (1996) Mixotrophy in Fragilidium subglobosum (Dinophyceae) growth and grazing responses as functions of light intensity. Mar Ecol Prog Ser 143:247-253

Smetacek V (1975) Die Sukzession des Phytoplankton in der westlichen Kieler Bucht. PhD thesis, Institut für Meereskunde, Kiel

Stoecker DK, Li A, Coats DW, Gustafson DE, Nannen MK (1997) Mixotrophy in the dinoflagellate Prorocentrum minimum. Mar Ecol Prog Ser 152:1-12

Strathmann RR (1967) Estimating the organic carbon content of phytoplankton from cell volume or plasma volume. Limnol Oceanogr 12:411-418

Strom SL (1991) Growth and grazing rates of the herbivorous dinoflagellate Gymnodinium sp. from the open subarctic Pacific ocean. Mar Ecol Prog Ser 78:103-113

Suttle CA, Harrison PJ (1988) Ammonia and phosphate uptake rates, N/P ratios, N:P supply ratios and evidence for $\mathrm{N}$ and $\mathrm{P}$ limitation in some oligotrophic lakes. Limnol Oceanogr 33:186-202

Tamiya H, Iwamura T, Shibata K, Hase E, Nihei $T$ (1953) Correlation between photosynthesis and light independent metabolism in the growth of Chlorella. Biochim Biophys Acta 12:23-40

Tranvik LJ, Porter KG, Sieburth JMCN (1989) Occurrence of bacterivory in Cryptomonas, a common freshwater phytoplankter. Oecologia 78:473-476

Walker LM (1984) Life histories, dispersal and survival in marine planktonic dinoflagellates. In: Steidinger KA, Walker LM (eds) Marine plankton life strategies. CRC Press, Boca Raton, p 19-34

Walker LM, Steidinger KA (1979) Sexual reproduction in the toxic dinoflagellate Gonyaulax monilata. J Phycol 15:3-12

Wawrik F (1970) Mixotrophie bei Cryptomonas borealis Skuja. Arch Protistenkde 112:312-313

Submitted: June 3, 1996; Accepted: December 18, 1997

Proofs received from author(s): April 22, 1998 